\title{
Sprawozdanie $\mathrm{z}$ konferencji „Współczesne zagrożenia wiary od zewnątrz"
}

Współczesność niesie ze sobą różnorodne ideologie. Wśród licznych przejawów dobra można zaobserwować niepokojące zjawiska, wobec których Kościół nie może przejść obojętnie. Z tą myślą Międzywydziałowa Katedra Teologii Katolickiej Uniwersytetu w Białymstoku w dniach 11-12 lutego 2010 roku zorganizowała Konferencję naukową połączoną z warsztatami duszpasterskimi dla księży archidiecezji białostockiej pod hasłem „Współczesne zagrożenia wiary od zewnątrz". Spotkanie odbyło się w Archidiecezjalnym Wyższym Seminarium Duchownym w Białymstoku. Zaproszonym prelegentem był ks. prof. dr hab. Bogdan Biela, pracownik Zakładu Teologii Pastoralnej i Historii Duszpasterstwa Wydziału Teologicznego Uniwersytetu Śląskiego w Katowicach. Ramowy program konferencji przedstawiał się następująco: 1) konferencja - prelekcja wygłoszona przez ks. prof. dr hab. Bogdana Bielę na temat „Współczesne zagrożenia wiary od zewnątrz”; 2) spotkania w grupach: gr. I: „Ideologia postmodernizmu” - prowadzący: ks. prof. dr hab. Jozef Zabielski; gr. II: „Indywidualizm antykościelny” - prowadzący: ks. dr Andrzej Proniewski; gr. III: „Problemy wynikające z migracji” - prowadzący: ks. dr hab. Adam Skreczko prof. UwB i UKSW, on też odpowiadał za prowadzenie całej Konferencji; 3) postulaty duszpasterskie, które były owocem dyskusji każdej z grup, zaprezentowane przez poszczególnych ich reprezentantów; 4) podsumowanie dyskusji czynione przez ks. abp. prof. dr. hab. Edwarda Ozorowskiego; 5) posiłek.

Ksiądz prof. dr hab. Bogdan Biela w swoim wystąpieniu, rozważając zagadnienie współczesnych zagrożeń godzących $\mathrm{w}$ wiarę, rozpoczął od postawienia fundamentalnego pytania: „Dlaczego ludzie odchodzą od religii?” Konkluzją stały się dwa słowa: „masowość cywilizacji” - „to ona sprawia, że niewiara nikogo nie dziwi”.

Nie sposób pochylić się nad tematem Konferencji bez analizy powszechnego zjawiska, jakim stał się ateizm. Przeto Ksiądz Profesor położył nacisk na dwa wymiary ateizmu, a mianowicie: jawność i skrytość. W pierwszym przypadku Bóg znika z życia człowieka; w drugim zaś - osoba deklaruje wiarę, ale żyje tak, jakby Boga nie było. W konsekwencji tego zjawiska rodzi się humanizm bez Boga. Prowadzi on do konkretnych zagrożeń wiary, wśród których Prelegent wymienił sekularyzację świata, niszczenie autorytetu Kościoła w dylematach moralnych, postmodernizm ze swym subiektywizmem prawdy, relatywizmem moralnym, liberalizmem etycznym, synkretyzmem religijnym, manipulacjami medialnymi propagującymi złe wartości i niewłaściwe wzorce moralne, mi- 
gracjami zarobkowymi. Te ostatnie mają cztery znamiona: nasilenie, zróżnicowanie, globalizacja i feminizacja. Wpływ migracji na wiarę oddziaływuje na migrantów i ich rodziny pozostające $w$ Polsce. Zwracając uwagę, że migracje rodzą się z braku nadziei, Ksiądz Profesor, wskazał konieczność podjęcia duszpasterstwa migracyjnego, które winno objąć migrantów (stwarzanie ośrodków polonijnych) i ich dzieci, które już teraz noszą miano eurosierot. Duszpasterstwo to ma ukierunkować się na budzenie nadziei.

Prelegent na koniec położył akcent na prowadzenie duszpasterstwa lokalnego, zwracając uwagę, że powinno ono opierać się na dynamizmie ewangeliczno-katechumenalnym. Parafie, aby stać się środkiem religijnego odniesienia wiernych, mają stać się domem i szkołą komunii.

Po wysłuchaniu Konferencji wszyscy jej uczestnicy dzielili się swoimi uwagami i postulatami w trzech grupach.

W grupie pierwszej, której przewodniczył ks. prof. dr hab. Józef Zabielski, rozważania ogniskowały się wokół zagadnienia ideologii postmodernizmu. Zwrócono uwagę na problem motywacji religijnej. Określono jej źródła: ideologia postmodernistyczna, która odcisnęła swoje piętno na przeciętnym katoliku, który niejednokrotnie wstydzi się swojej wiary; nihilistyczny i hedonistyczny styl życia, upatrujący cel egzystencji w realizacji wszelkich pragnień i pożądań ludzkich; słabość, a wręcz szkodliwość nauczania religii w szkołach, które przybrało kształt lekcji, co w konsekwencji sprowadziło katechezę do przepytywania $\mathrm{z}$ katechizmu, dlatego postulowano odbudowę katechezy parafialnej, która kształtowałaby osobowość ogólnoludzką i chrześcijańską dzieci i młodzieży; masowość duszpasterstwa, w którym parafianie są anonimowi; niski poziom szkolnictwa, który już nie wychowuje, a często deprawuje młodego człowieka.

W grupie drugiej, której przewodniczył ks. dr Andrzej Proniewski, dyskutowano na temat indywidualizmu antykościelnego. Określono jego powody. Wśród nich zaakcentowano demoralizujący styl prowadzenia katechezy, wzajemne podważanie autorytetu przez katechetów, krótkie i nacechowane materializmem wizyty duszpasterskie, brak kontaktu duszpasterzy z parafialnymi rodzinami, dużą anonimowość parafian, wynikający z formalizmu duszpasterzy.

W grupie trzeciej rozważania koncentrowały się wokół duszpasterstwa migrantów i ich rodzin pozostających w Polsce. Można wymienić następujące postulaty: należy w parafiach informować przyszłych migrantów o ośrodkach polonijnych (spis duszpasterstw polonijnych), z racji tego, że migracja jest motywowana przygodą, należy ich informować, co ich czeka za granicą. Problemem migracyjnym są związki nieformalne - należy zatem przy "kolędzie” uwrażliwiać na tę sprawę. Duszpasterstwem winno też objąć rodziny pozostające w Polsce - dla nich dobrze by było organizować wspólne Msze Święte. Okazją dla duszpasterstwa migracyjnego jest powrót świąteczny migrantów 
do Polski - wówczas można zachęcać ich do praktykowania życia religijnego. Praktykowanie to musi unikać tworzenia swoistych gett polonijnych. Dobrym świadectwem wiary byłoby uczestnictwo Polaków we wspólnej Mszy Świętej z rodzimą społecznością. Problemem jest zjawisko wypisywania się migrantów z Kościoła, brak tożsamości religijnej, ujawniający się w wielu sytuacjach, np. kiedy przychodzi do ks. proboszcza w Polsce rodzina migranta, który ma być chrzestnym $z$ prośbą o wystawienie świadectwa praktykowania życia religijnego, które powinno być wystawione w parafii zagranicznej migranta. Postulatem $\mathrm{w}$ tym względzie jest meldowanie się nowo przybyłego w parafii za granicą.

$\mathrm{W}$ podsumowaniu dyskusji ks. abp prof. dr hab. Edward Ozorowski zwrócił uwagę na inne problemy, niewymienione przez prelegenta: tzw. churchializm ludzie przystępują do poszczególnych sakramentów w różnych parafiach oraz niszczenie autorytetu księży. Jego Ekscelencja określił drogę ratowania wiary: „Ratunkiem dla zachowania wiary jest 3 razy «communio»: między księżmi, między księżmi a wiernymi, między księżmi a arcybiskupem”.

Po obradach wszyscy uczestnicy udali się do refektarza AWSD na wspólny posiłek.

Anna Dzięgielewska Uniwersytet $w$ Białymstoku 